Case Report

\title{
Did the baroque composer Domenico Scarlatti have watch glass nails and drumstick fingers?
}

\author{
Andreas Otte 1 \\ 1 Laboratory of NeuroScience, Division of Medical Engineering, Department of Electrical Engineering, \\ Medical Engineering and Computer Science, Offenburg University, Badstr. 24, D-77652 Offenburg, \\ Germany; andreas.otte@hs-offenburg.de
}

\begin{abstract}
Background: Little is known about the baroque composer Domenico Scarlatti (1685-1757), whose life was centred behind closed doors at the royal court in Spain. There are no reports about his illnesses. From his compositions, mainly for harpsichord, an outstanding virtuosity can be read. (2) Case Presentation: In this case report, the only known oil painting of Domenico Scarlatti is presented, on which he is about 50 years old. In it one recognizes conspicuous hands with hints of watch glass nails and drumstick fingers. (3) Discussion: Whether Scarlatti had chronic hypoxia of peripheral body regions as a sign of, e.g., bronchial cancer or a severe heart disease, is not known. (4) Conclusions: The above-mentioned signs recorded in the oil painting, even if they were not interpretable at that time, are clearly represented and recorded for us and are open to diagnostic discussion from today's point of view.
\end{abstract}

Keywords: Domenico Scarlatti; oil painting; watch glass nails; drumstick fingers; clubbing; Pierre-Marie-Bamberger syndrome

\section{Introduction}

Not much personal information is known about the life of Domenico Scarlatti (born in 1685 in Naples, died in 1757 in Madrid), a baroque composer and harpsichord virtuoso famous for his 555 harpsichord sonatas. Scarlatti's many years as a teacher and composer behind the closed doors of the Spanish royal house meant that during his lifetime he did not receive the same public attention as his contemporaries Handel or Bach, who were born in the same year. The most extensive research was conducted by the US harpsichordist Ralph Kirkpatrick (born 1911, died 1984) [1]. In Kirkpatrick's engrossing book on Scarlatti's biography most of the little volume is devoted to many other interesting subjects, especially on Scarlatti's compositional oeuvre.

\section{Case Presentation Section}

The oil painting (Figure 1), which the painter Domingo Antonio Velasco created around 1738 on the occasion of Scarlatti's appointment as Knight of the Order of Santiago, is the only known portrait of Scarlatti.

In this painting he has an age of about 50 years. It can be seen in the Casa dos Patudos, Museu de Alpiarça/Câmara Municipal de Alpiarça in Portugal. Assuming that this is a realistic depiction of the composer, his two slender hands are striking: on the right with slightly longitudinally curved and large nails (this is particularly noticeable on the index finger) and on the left with tapered and slightly widened fingers, to be interpreted in the sense of drumstick fingers (Figure 2). 


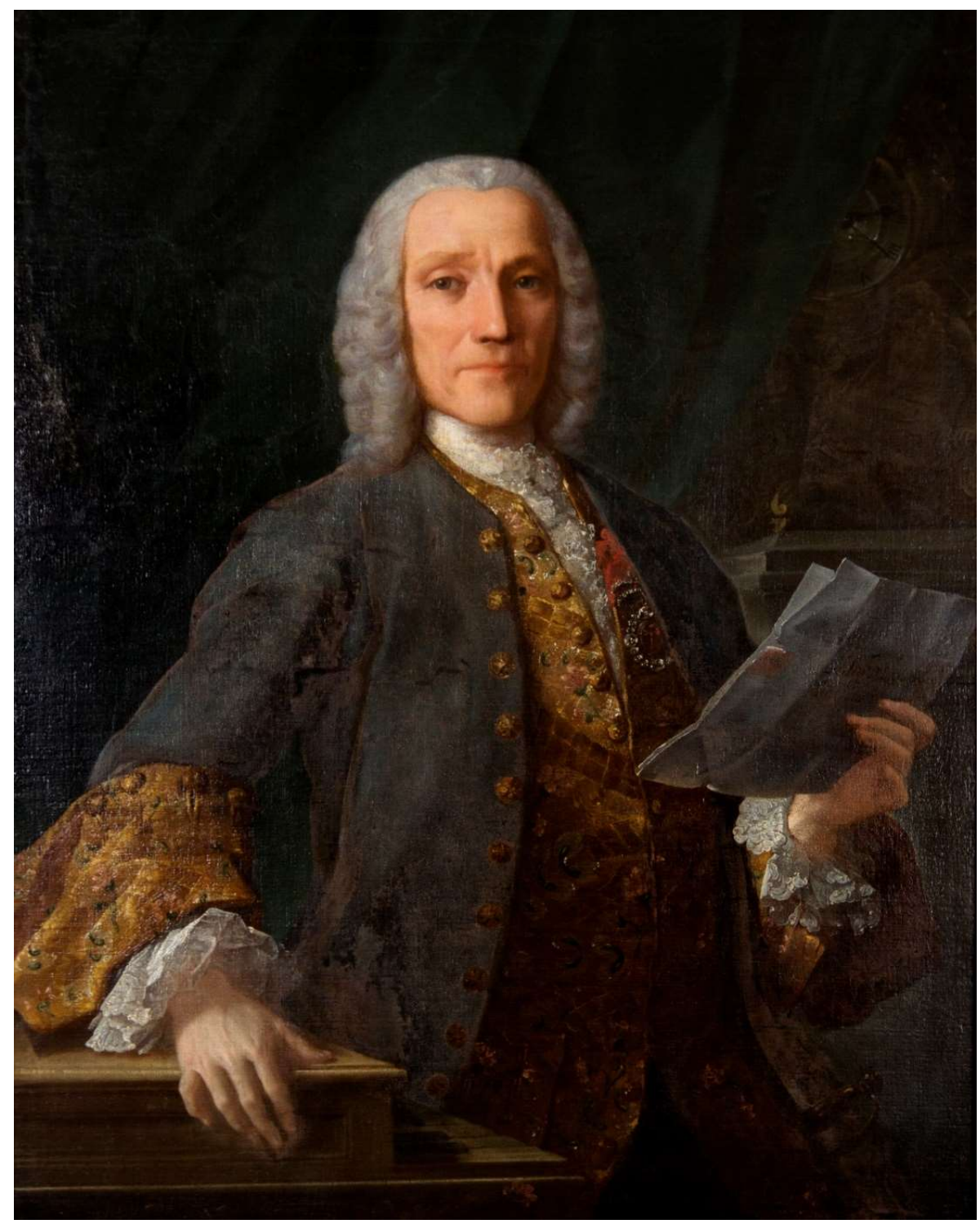

Figure 1. Domenico Scarlatti (1685-1757), about 1738, oil painting by Domingo Antonio Velasco. Picture credits: Serviço Técnico da Casa dos Patudos - Museu de Alpiarça /Câmara Municipal de Alpiarça, Portugal. With kind permission. 


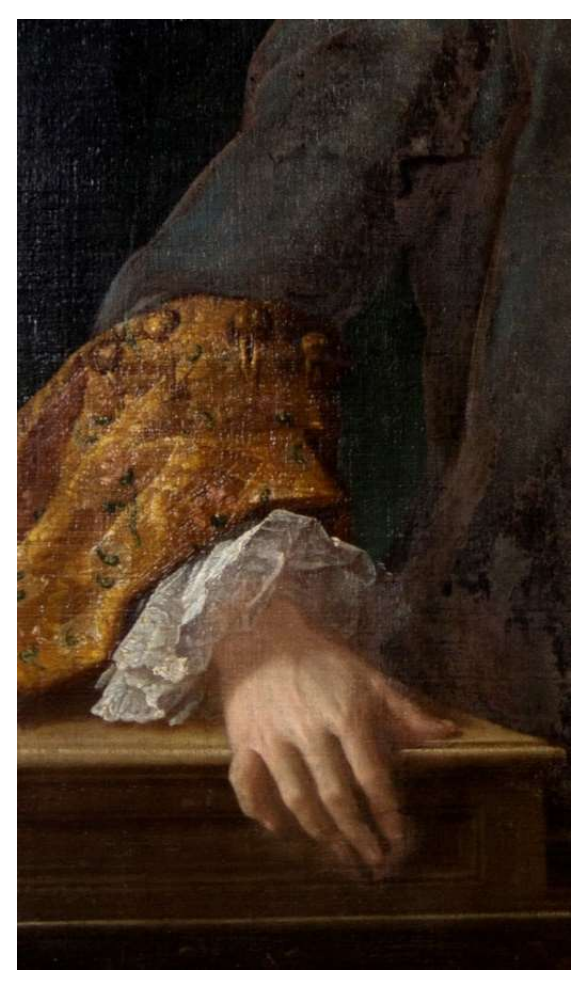

(a)

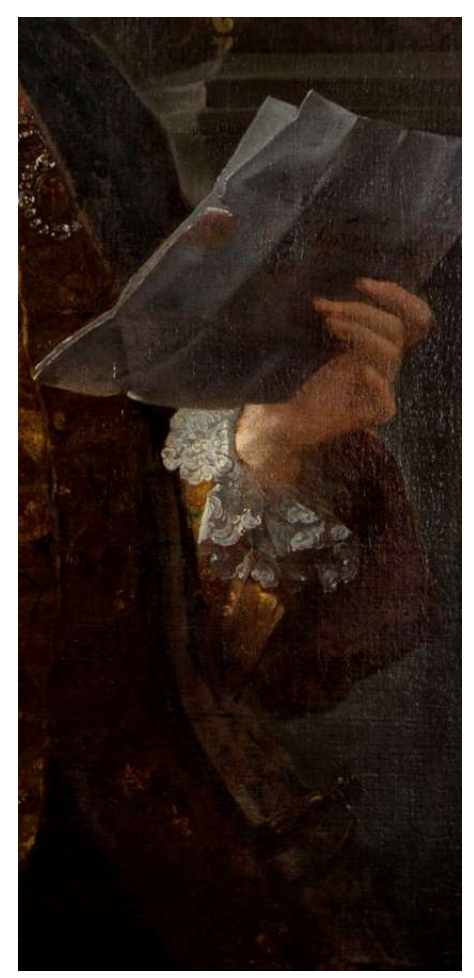

(b)

Figure 2. Domenico Scarlatti (1685-1757), about 1738, oil painting by Domingo Antonio Velasco. Picture credits: Serviço Técnico da Casa dos Patudos - Museu de Alpiarça /Câmara Municipal de Alpiarça, Portugal. With kind permission: (a) Right hand detail; (b) Left hand detail.

\section{Discussion}

Drumstick fingers, on one or both sides and often associated with watch glass nails, commonly referred to in the literature as "clubbing", are signs of chronic hypoxia of peripheral body regions, which-among many other possible reasons-can usually be caused by pulmonary or heart diseases and should in any case be considered as early signals of serious disease. They are caused by hyperplasia and hypertrophy of soft tissue and periosteum, known as hypertrophic osteopathy or Marie-Bamberger syndrome, and were first described by Hippocrates approximately 450 B.C. [2, 3]. Marie Bamberger syndrome is also known as paraneoplastic syndrome because lung tumours can be a common cause and more than $90 \%$ of cases are associated with a small cell lung carcinoma. In this case Scarlatti probably would not have lived so long (in the portrait he was approximately 50 years old, but he turned 71). The differential diagnoses for drumstick fingers are chronic arterial hypoxia (restrictive lung diseases, obstructive pulmonary diseases, cyanotic heart defects) and very rarely other diseases such as inflammatory bowel diseases (sprue), thyroid and liver diseases, endocarditis or tuberculosis [3]. Considering the chance of survival for this differential diagnostic list, Scarlatti may well have suffered from one of these diseases.

Unlike other famous personalities like Beethoven [4], Paganini [5, 6], Bach [7] or Ravel [8], to name but a few, we know nothing about Scarlatti's pathography. The telltale fingertips depicted in the oil painting are the only evidence of a potential serious illness of Scarlatti. It may be speculated whether he only had long fingernails, which may be shown on the painting (see Figure 2A). But since his instrument was the harpsichord, it can hardly be assumed. 
Unfortunately, unlike his contemporary Johann Sebastian Bach [7], to the best of our knowledge nothing is known about Domenico Scarlatti's health and life style (e.g., smoking, alcohol consumption, or eating habits) to support the potential cause of this condition. Therefore, the presented case report can be classified as unusual and speculative, although it might reveal interesting new aspects. But perhaps one day, as new information or sources are discovered, this case report, albeit speculative, will help to bring more light into Scarlatti's health status and life.

\section{Conclusions}

Painters of the past, who depict nature realistically, can show us interesting aspects of the diseases of that time, which are otherwise not reported and which, although not known at that time, were already captured in a painting [e.g., 9, 10].

Funding: This research received no external funding.

Conflicts of Interest: The author declares no conflict of interest.

\section{References}

1. Kirkpatrick R. Domenico Scarlatti. Princeton: Princeton University Press; 1953.

2. Uppal S, Diggle CP, Carr IM, et al. Mutations in 15-hydroxyprostaglandin dehydrogenase cause primary hypertrophic osteoarthropathy. Nat Genet. 2008;40:789-793.

3. Manger B, Lindner A, Manger K, Wacker J, Schett G. Hypertrophe Osteoarthropathie. Marie-Bamberger-Syndrom [Hypertrophic osteoarthropathy. Bamberger-Marie disease]. Z Rheumatol. 2011;70:554-560.

4. Otte A. Beethoven's autopsy report. Science. 2020: e-letter: https://science.sciencemag.org/content/337/6090/30/tab-e-letters [published online 5 Aug 2020].

5. Otte A. Nicolò Paganini: Teufelsgeiger durch abnorme Hände? - Neue Untersuchungen eines Bronzegipsabgusses der rechten Hand. [Nicolò Paganini: Devil's violinist because of abnormal hands? New investigations using a bronze cast from the right hand]. Arch Kriminol. 2014;233:181-191.

6. Otte A, Kijewski H. Nicolò Paganinis Haarlocke für Signora Chatterton -morphologische Haaruntersuchungen mittels digitaler Lichtmikroskopie. [Nicolò Paganini's hair lock for Signora Chatterton - morphological hair investigations using digital light microscopy]. Arch Kriminol. 2016;238:153-172.

7. Otte A. Johann Sebastian Bach's remains: Part III - the pathography. Arch Kriminol. 2019;244: 116-121.

8. Otte A, De Bondt P, Van de Wiele C, Audenaert K, Dierckx R. The exceptional brain of Maurice Ravel. Med Sci Monit. 2003;9:RA133-138.

9. Lahita R, Asensi V, Lippi D, Perciaccante A, Charlier P, Appenzeller O, Bianucci R. Evidence of hypothyroidism in a portrait by Lorenzo Lotto. Lancet Diabetes Endocrinol. 2019; 7:14.

10. Otte A. Hatte Maria einen Jodmangel? MMW Fortschr Med. 2019; 161:7. 